.

\title{
Extraordinary Legal Remedies in the Administrative Conflict
}

\author{
Xhemazie Ibraimi* \\ Faculty of Law, AAB College, Prishtina -Fushë Kosovë, 10000 Prishtina, Kosovo \\ *E -mail of the corresponding author: xhemazie.ibraimi@universitetiaab.com
}

\begin{abstract}
This paper deals with the importance of administrative conflict as a guarantee in the realization of the rights and interests of citizens in a particular procedure and by a special body not the administrative body but judicial body and judicial procedure.We have also made efforts to provide data on the efficiency of the activities of the administration bodies in the fulfillment and realization of their obligations towards the realization of the citizens rights and interests.Human rights do not stand in the vacuum, their protection mechanisms exist because public administration bodies violate them during their daily administrative / executive activity. This paper analyzes the non-implementation of the constitutionality and legitimacy principle in decision-making by the administration bodies and the use of other mechanisms such as regular and extraordinary legal remedies to fix the illegality and irregularities made by the administration bodies. Through this paper we will use the comparative method of administrative conflict of two legal systems based on the Legislation of the Republic of Macedonia, and based on the legislation of the Kosovo. Other important issues will be addressed such as the use of more extraordinary legal remedies in the judicial administrative procedure under Kosovo legislation and the importance of resolving administrative misdemeanor by the Administrative Court of Macedonia.
\end{abstract}

Key words: Administrative activity, administrative conflict, remedies, Administrative Court

DOI: $10.7176 / \mathrm{JLPG} / 87-19$

Publication date:July $31^{\text {st }} 2019$

\section{Introduction}

In a democratic state, the principle of separation and balance of powers does not only require non-intervention in the competences of bodies belonging to different powers, but also requires mutual cooperation between them, while the specific purpose of each body that belongs to the powers of different is the strengthening of democracy in the interest of the country.

The principle of institutional cooperation has two dimensions as well; negative and positive; negative because it should not be interfered but the competencies of each body should be respected from the other and positive because it must actively cooperate and need support among the organs in order to fulfill constitutional obligations. ${ }^{1}$ The constitution as the basic law of the state obliges all state and public authorities to exercise their powers solely within the framework and under constitutional norms according to the principle of constitutionality and legality. Public authorities in fulfilling their duties should respect fundamental human rights and freedoms and contribute to their realization. ${ }^{2}$

The constitution as the basic law of the state obliges all state and public authorities to exercise their powers solely within the framework and under constitutional norms according to the principle of constitutionality and legality. Public authorities in fulfilling their duties should respect fundamental human rights and freedoms and contribute to their realization. Human rights are not in the vacuum, their protectionism exists because the public administration bodies violate them during their daily administrative / executive activity. Respecting human rights at an administrative level means that the administration operates in accordance with the required constitutional standards for an administrative activity. Public administration bodies should respect and enforce the constitutional principles that, through their activity, enable to built the state of law and democratic state to guarantee human rights and fundamental humans freedom.

${ }^{1}$ Elsa Toska, Control over administrative activity according to the practice of the Constitutional Court of Albania, Tirana, 2013. pg.188.

${ }^{2}$ Ibid., pg.6. 
Exceptions even when the public administration bodies do not respect and enforce the law by violating human rights, the Constitution has foreseen protective mechanisms to regulate illegality and to strike an unlawful decision against a higher instance such as Administrative Conflict, regular and extraordinary legal remedies in an administrative conflict. The Constitution of each state guarantees also when the rights of citizens are affected in the regular administrative procedure by administrative bodies, those rights are realized and regulated in a special procedure and a special body no administrative body but a judicial body.In this situation arises the conflict or disagreement with the administrative organ regarding the subjective right and the legality of the administrative a

\subsection{An appeal to the Administrative Conflict in RM}

By interpreting the provisions of the new Law on Administrative Conflicts relating to the right to initiate a complaint against judgments issued in an administrative dispute (Article 39 paragraph 2 and Article 30, paragraphs 2 and $3,{ }^{1}$ it can be concluded that the Law foresees the possibility the appeal should be initiated in cases when the court issues the judgment after holding a public hearing due to the complexity of the case in an administrative dispute for a better review of the state of affairs when it establishes a factual situation when it issues facts and when it decides because of silence of the administration.

It can be concluded that this election is largely different from previous legal choice ${ }^{2}$, where (Article 19) provided for the possibility of appeal against decisions issued in an administrative confiscation only if it is foreseen by law for certain matters. Based on this legal choice, it may be recognized the intention of the legislator to allow the implementation of a regular remedy in cases where the Administrative Court establishes a factual situation ${ }^{3}$, issues facts, or makes a decision because of the silence of the administration, or when it comes to serious and complicated issues.Giving the opportunity to initiate a complaint in these situations also means the possibility of correcting the first instance verdict.

\section{Extraordinary Legal Remedies in the Administrative Conflict of RM}

Unlike the earlier legal election that enables the use of extraordinary legal remedies, the request for protection of legality and the repetition of the procedure, the current legal choice as an extraordinary legal remedy only foresees the repetition of the procedure.

This legal choice is, above all, a result of the assessment that this extraordinary legal remedy is unnecessary, especially if consideration is given to the regular remedies that can be used in the general legal procedure and in the administrative judicial procedure. The possibility that in the general administrative procedure, the control of the administrative act be done with the regular legal remedy the appeal and seven extraordinary legal remedies in the procedure: repeating the administrative procedure, changing and annulling the decision regarding the administrative conflict, annulment of the decision under the right of supervision, annulment and annulment of the final decision with the consent or at the request of the party, extraordinary rendering of the decision, declaration of invalidity, ${ }^{4}$ as well as in the administrative and judicial procedure to use the right of appeal as a regular legal remedy, provides the possibility of extensive control in the protection of the legality of administrative acts. Therefore, the assessment is that the use of more extraordinary remedies in the judicial administrative procedure would slow down and charge even more the same one.

\section{Repeated administrative judicial proceedings}

An indispensable condition for the initiation of an extraordinary legal remedy: "The repetition of a judicial administrative procedure" is the existence of a final judicial decision. The judgments, respectively the decisions

\footnotetext{
${ }^{1}$ Law on Administrative Conflict, Official Gazette of the Republic of Macedonia, 62/2006.

${ }^{2}$ Official Gazette of SFRY, No. 4/77.

${ }^{3}$ Law on Courts, Official Gazette of RM, no. 58/06, 35/08.

${ }^{4}$ Law on General Administrative Procedure, Official Gazette of the Republic of Macedonia no. 26/2005.
} 
of the first instance court, become final by issuing them respectively by sending them to the parties.Procedura e përfunduar me aktgjykim apo aktvendim do të përsëritet me kërkesë të palës:

1. If a party learns about new facts, finds the opportunity to use the basic facts of which conflict resolution would be more appropriate to the party if such facts or evidence were used in the previous procedure (to a reopening of the proceedings may be required due to new facts or evidence, it is necessary that the facts or evidence that are proposed to have existed during the previous administrative and judicial proceedings, while the proposer of the proceedings for such facts or evidence has not been aware or was prevented from using them.

So this is about facts or evidence which existed earlier, but for that it is understood as being issued a final court decision. If the proposer of the repetition of the proceedings issues facts that have occurred after the procedure has been completed by a final court decision, such facts can not serve as a cause for the repetition of the judicial administrative procedure, but based on such facts may be required new administrative procedure and issuance of new administrative act.

It is not enough to talk about any new fact, but it is necessary to talk about facts and evidence that will make it possible to make the most appropriate decision for the party.

Based on it, if the judicial administrative procedure has ended with the dismissal of the indictment, then it should be a matter of new facts or evidence that will enable the annulment of the administrative act that was a matter of deciding the court of law first. Repeal of the administrative judicial procedure can not be requested if the court has not established the factual situation but resolved the conflict based on the facts established in the administrative procedure or if the decision was annulled because the factual situation in the administrative procedure is not fairly certified;

Reopening of the procedure due to new facts can only be requested by the person who has been a party to the proceedings but not the other persons, the acknowledgment of receipt of the order in the mail does not represent a new fact for the repetition of the administrative and judicial procedure, repeat the procedure for due to new facts and evidence can only be sought if the new facts and evidence existed at the time it was decided on the petite that was the subject of the proceedings. Even in cases when the ombudsman ${ }^{1}$ proposes a repeat of the specified procedure such repetition is only possible under the conditions provided by law;

2. Whether a court decision has been reached due to a criminal offense of a judge or an official at a court or the decision has been influenced by the fraud of a legal representative or a party's authorized representative, whereas such action constitutes a criminal offense. (In order to be able to repeat proceedings on this basis it is necessary that the criminal offense of the persons mentioned in the provision be certified by a criminal court judgment. Criminal acts should directly affect the procedure, if there is a strong link between the offense and the issued court decision;

3. If the decision is based on a judgment rendered in criminal or civil proceedings, which has subsequently been annulled by a final court decision;

4. If the document on which the decision is based is false or if the witness, expert or the party hearing the evidence before the court gives false testimony while the court's decision is based on that evidence (the question is how to ascertain the inaccuracy or the inaccuracy of the document or the veracity of the testimony of witnesses, experts or parties). Undoubtedly, a repetition of the administrative and judicial procedure will be possible when the authenticity of the document or the veracity of the testimony of the witness, the expert or the party will be proven in the criminal proceedings. Judicial practice has taken a stand in certain cases even the court in the administrative and judicial procedure, can prove the authenticity of the document and not only through the final judgment of the criminal court;

5. If a party finds the opportunity to use the previous decision issued in the same administrative dispute (in such situation it can be made when two verdicts are issued for the same administrative act: eg if the same administrative act is contested also the lawsuit of the party also by the authorized state body, while the court has issued to merge the two lawsuits and to issue a judgment, but based on each lawsuit has issued different verdicts);

6. If the person concerned has not been given the opportunity to take part in an administrative dispute;;

${ }^{1}$ Daneva-Pavlovska Ana, Ombudsman, Skopje, 2000. 
7. Based on the decision of the European Court of Human Rights..

The requirement to allow a repetition of the procedure is that the party without fault has not been able to provide such facts in the previous judicial proceedings. From the legal text we can conclude that the reasons for the repetition of the administrative and judicial procedure are of a technical and non-legal nature. Regarding the repetition of the procedure, a very important question is raised: the shortcomings in the factual situation due to which the recourse to the administrative and judicial procedure may be repeated is a lack of administrative procedure or administrative procedure. The answer to this question should be sought in the intent of (Article 43) of the Law on Administrative Procedure, ${ }^{1}$ on the basis of which it can be concluded that the reasons for the repetition of the administrative administrative procedure should be related to the factual situation as certified by the first instance court. On the basis of this, if some of the reasons mentioned for the repetition of the procedure relate to the factual situation established in the administrative procedure, which was not subsequently changed in court proceedings, such cause can not be a condition for repetition of the administrative judicial procedure .

Reopening of the procedure may only require persons who have participated in the conflict after the issuance of the verdict respectively the ruling, while such persons are: the plaintiff, the state body respectively the organization whose act is annulled and the person concerned if the contested act is canceled. From the legal provisions we can conclude that repetition of the procedure can not be initiated by the court with an official duty (ex oficio). Repeal of the administrative judicial procedure may be requested within a specified legal deadline. The first deadline is subjective, while the second deadline is objective.

A party may request a repetition of a judicial administrative procedure not later than 30 days from the day on which the cause of repetition has been understood. If a party for the reason of the repetition of the judicial administrative procedure has understood before the court proceeding is terminated and the cause can not be used during the course of the proceedings, the repetition may be requested within 30 days from the day the decision is delivered to the party Article 41, paragraph 1) of the Law on Administrative Conflict. ${ }^{2}$ This is a subjective deadline for the repetition of judicial administrative proceedings.

Repeal of the administrative administrative procedure can not be requested after the time limit of 5 years, from the lawfulness (Article 44, paragraph 2) of the Law on Administrative Conflict. This is an objective or absolute term for repetition of a judicial administrative procedure. The objective deadline for repetition of a judicial administrative procedure begins to run from the day the decision is delivered to the party.After the indictment for repetition of the procedure, the court that has brought the same decision that has to do with the reason for the repetition of the procedure is decided (Article 45 of the Law on Administrative Conflict). The indictment for the repetition of the procedure is submitted to the competent court for placement (Article 46, paragraph 1), by the Law on Administrative Conflict. It is the Administrative Court of the first instance that issued the verdict. The Law on Administrative Conflict also foresees the manner in which the indictment for repetition of the procedure (Article 46, paragraph 2) of the Law on Administrative Conflicts is to be filed.

The indictment should contain: the verdict respectively the ruling issued in the procedure for which the decision is required for repetition, the legal basis for which repetition is requested and the facts, respectively the circumstances that make it possible to exist that basis, the circumstances from which it can be concluded that the indictment is filed within the foreseen timeframe as well as the evidence for it, the direction and to what extent it proposes a change of the judgment respectively the ruling issued in the procedure for which a repetition of the procedure is required.

The prosecution for repetition of the court administration procedure is filed in the same manner as the lawsuit filing the initiation of the administrative conflict.On the indictment for repetition of the procedure is decided on a non-public hearing (Article 47, paragraph 1) of the Law on Administrative Conflict.When deciding on the indictment for repetition of the procedure two stages are distinguished:

${ }^{1}$ Law on General Administrative Procedure, Official Gazette of the Republic of Macedonia no. 26/2005

${ }^{2}$ Law on Administrative Conflict, Official Gazette of the Republic of Macedonia, 62/2006. 
- In the first phase, the court examines whether or not the claim has been filed within the prescribed timeframe and whether there is a cause for repetition of the proceedings. The court will dismiss the accusation for repeating the procedure by a ruling if it finds that the indictment was filed before the legal deadline, if the indictment was filed by the unjusted person and if the party did not justify the existence of the legal basis for repetition.

If the party has not made the circumstance on which the repetition of the proceedings is based, the defendant body in that case in accordance with the Law on Administrative Conflict will reject the proposal. If the court does not reject the indictment in the preliminary procedure, the same will hand it over to the opposite party and the person concerned and invite them to respond to the indictment within 15 days. The deadline for responding to the indictment is a deadline determined by law, which means that this deadline can not be extended or shortened by the court.

After the expiry of the deadline for the response to the indictment, the court for the indictment for repetition of the procedure decides by a verdict.

If the repetition of the procedure is allowed, the earlier decision will be annulled in whole or in part, while the previous procedural actions against which the reopening cause does not affect the court will not repeat it. The recurring procedure ends with a ruling by which the earlier ruling that was a matter of repetition is annulled or replaced entirely by a new ruling by which the previous ruling is annulled or revoked. Against the decision of the court issued on the basis of the aktacia for repetition of the procedure, a request for protection of legality may be initiated before the Supreme Court of the Republic of Macedonia.

\section{Extraordinary remedies in administrative conflict in $\mathbf{C R}$}

In contrast of from the legislation of the Republic of Macedonia, which foresees only the use of an extraordinary legal remedy in the judicial administrative procedure, and the repetition of the procedure, justifying the fact that the parties were given a broad opportunity to influence in the regular administrative procedure on the corrections of the rulings, the use of more extraordinary remedies in the administrative court procedure would also lead to the burden and the slowdown in the work of the courts. ${ }^{1}$ The RK legislation of this issue is regulated in different ways while providing more party alternatives in administrative judicial procedure despite regular judicial administrative proceedings where the party is guaranteed seven emergency vehicles, even in administrative proceedings Law for Administrative Conflict guarantees that against judgments issued in the administrative court procedure the party has the right to initiate a complaint as well as three extraordinary remedies also:

1. Review of the final court decision,

2. Request for Extraordinary Review of Judgment, and

3. Request for Protection of Legality. ${ }^{2}$

\subsection{Review of final court decision}

The revision of a final judicial decision is an extraordinary legal remedy that is used against a court decision that has become final, even in a subjective term of 30 days, and in a target period of 3 years from the day when the court decision has take the cut. This extraordinary legal remedy can be initiated by a party if it learns about new facts and evidence on the basis of which the administrative conflict would be resolved differently, more suitably to the party. This extraordinary legal remedy is initiated upon request, concludes with a judgment and upon the request is decided by the same court which has established the administrative conflict.

${ }^{1}$ Law on Administrative Conflicts of the Republic of Macedonia, "Official Gazette of the Republic of Macedonia, no. $62 / 2006 "$

${ }^{2}$ Law on Administrative Conflicts of the Republic of Kosovo, no. 03 / L-202. 


\subsection{Request for Extraordinary Review of Judgment}

The request for extraordinary review of the court decision as an extraordinary remedy may be filed against a final court decision, even within a subjective time of 30 days from the day of delivery of the final judgment to the party if the provisions have been violated legal material as well as if the rules of procedure have been violated.On this extraordinary legal remedy, the Supreme Court of the CC decides to dismiss the claim if it is presented before or after the legal deadline if it finds that there is no legal violation and can approve the request if it finds that the claim is grounded.

\subsection{Request for Protection of Legality}

The request for the protection of legality is an extraordinary legal remedy that can be filed by the public prosecutor against a final court decision, if it considers that by such verdict the law or the general act has been violated. Based on this extraordinary legal remedy, the Supreme Court of RK decides. This extraordinary legal remedy may be filed within 90 days from the day of final delivery to the party.

The court may dismiss the request for protection of legality if it finds that it has been submitted before or after the expiry of the legal time limit if it finds that there is no violation of the substantive law or procedural provisions and may approve the request if it considers that there are violations of law and in this case annul the court decision against which the request for protection of legality has been filed and in this case the Supreme Court returns the case to the court whose decision has been annulled. This court is obliged to undertake all procedural actions and to consider the issues in which the court has decided on the request for protection of legality.

\section{Conclusion}

To provide a form of understanding of administrative activity is a difficult process because the executive is more focused on the realization of certain objectives and policies of general interest, thus exiting formal and substantial constitutionality and generally the constitutional requirements. On the other hand, the individual is more concerned with administrative decisions because in everyday life these kinds of decision-making dictate the quality of life, eg. a new tax, a refusal permit, a delay in retirement procedures, a private activity exercise that affects the quality of the environment. Undoubtedly constitutional rights affect the administrative activity, budget, competence, and up to the daily routine of public administration. ${ }^{1}$

Public administration should respect constitutional rights, principles and values when implementing its policies. Of course, it has discretion and room for assessment of the type of instruments it chooses to implement certain policies and achieve results. Through the constitutional process, the selected instruments are controlled, but without interfering with the competences pertaining to the legislature and the executive.

For administration bodies to be efficient in the implementation of their administrative activity it is necessary:

- Fair interpretation of normative and individual acts with the Constitution and the Law,

- Rational interpretation of Laws with the Constitution,

- Extending a due legal process with all its elements in any administrative proceeding where it is likely to violate the rights of individuals or their interests,

- Adequacy to some extent of the extent of the trial in quasi-judicial proceedings, when the act by its nature requires special technical knowledge,

- Adequacy of respecting a due legal process when the body by its nature is of a political nature,

${ }^{1}$ David H.Rosenbloom/James D. Carroll:“Toward Constitutional Competence. A casebook for public administrators”, 1990, Prentice Hall Inc, fq.32-33. 
- Selection of the most effective and least harmful means in the amount of alternatives for achieving a certain goal,

- Integration of constitutional values into administrative practices,

- Compliance of (opportunity) administrative requirements with constitutional requirements.

The wider the administrative competences of the administrative bodies, the more the judicial control over them in general and the constitutional control in particular need to be increased and intensified. Administrative proceedings are an integral part of human rights. Procedural guarantees in administrative proceedings along with the court access to protect these guarantees constitute fundamental and constitutional rights for the individual, referral to administrative provisions during a judicial process helps administrative authorities during their activity and implementation of certain policies to act with responsibility for issues that may create premise for human rights violations in the future.

\section{Bibliography}

- $\quad$ Stavileci, Esat. Introduction to Administrative Sciences, Pristina, 1997.

- Stavileci, Esat. Notions and Principles of Public Administration, Pristina, 2007.

- Stavileci, Esat. Sokoli, Agur. Batalli, Mirlinda. Administrative Law, Administration, Control, Responsibility and Computerization, Prishtina, 2010.

- $\quad$ Stavileci, Esat. Batalli, Mirlinda. Sadushi, Sokol. Administrative Law, Organization and Administrative Activity, Prishtina, 2012.

- Dobjani, Ermir. Administrative Law, Tirana, 2003.

- Dobjani, Ermir. Puto, Erlir. Toska, Ela. Get away, Erajd. Control over Public Administration, Tirana, 2013.

- Pollozhani, Bajram. Salihu, Lazim. Administrative Procedure and Administrative Conflict, logos-A, 2004

- $\quad$ Sadushi, Sokol. Administrative Law 2, Third Revised Edition, Tirana, 2005.

- Toska, Ela. Control over Administrative Activity according to the Practice of the Constitutional Court of Albania, Tirana, 2013.

- Sokoli, Agur. Control of Administrative Work and Its Political Responsibility, Pristina, 2009

- Sokoli, Agur. Administrative Procedural Law, Pristina, 2014.

- Ibraimi, Xhemazie. Compulsiveness of the Verdicts, International Magazine for Social Sciences "VIZIONE", ISSN, 1409-8962, Skopje, January, 2014.

- Ibraimi, Xhemazie, Administrative Dispute - Instrument of Legality Control of Administrative Acts and Protecting Rights and Freedoms of Citizens, International Magazine "JUSTICIA", ISSN 1827-8454 UDC: 34 Tetovo, March, 2014.

- Ibraimi, Xhemazie. Case of Administrative Dispute, ISSN 2410-3918 (Print), ISSN 2410-8693 (online), IMPACT FACTOR, November, 2015.

- Ibraimi Xhemazie, Reasons for Cancellation of Administrative Decision by Administrative Court, Academic Journal of Business, Administration, Low and Social Sciences, ISSN 2410-8693, ISSN 2410 3918, Korik, 2016.

- Gelevski, Simeon. Grizo, Naum. Davitkovski, Borce. Administrative Law, Skopje, 1997.DanevaPavlovska Ana, Ombudsman, Skopje, 2000.

- Gelevski, Simeon. Administrative Process Law, Skopje, 2003.

- Grizo, Naum. Gelevski, Simeon. Davitkovski, Borce. Daneva-Pavlovska, Ana. Public Administration, Skopje, 2008.

- $\quad$ Gelevski, Simeon. Davitkovski, Borce. Grizo, Naum. Administrative Law, Skopje, 2011.

- Grizo, Naum. Gelevski, Simeon. Davitkovski, Borce. Daneva-Pavlovska, Ana. Administrative Law, Skopje, 2008.

- $\quad$ Borkovic, Ivo. Administrative Law, Zagreb, 1987.

- $\quad$ Popoviq, Slavoljub. Administrative Dispute in Theory and Practice, Belgrade, 1979. 
- Stjepanoviq, Nikola. Administrative Law, Belgrade, 1991

- Law on Administrative Conflict of RM, Official Gazette of RM no.62 / 06.

- Law on Administrative Disputes of the Republic of Kosovo, no. 03 / L-202; 